\title{
Art Libraries Subsection ACRL
}

Theme: The Art Subsection as a national forum for college and research art libraries.

Tuesday, June 24 (Time to be announced)

Organizational Meeting

Open Forum on reorganization of the Art Subsection

Wednesday, June 25

8:00 a.m.-6:00 p.m. All day tour via bus to Princeton University

Visit Art Library and Index of Christian Iconography

Luncheon. Members and Art Librarians only.

Send advance reservations and deposit $(\$ 3.00)$ to:
Miss Phyllis Hoffberg

Program Chairman-Art Libraries

Fine Arts Library-Furness Building

University of Pennsylvania

Philadelphia, Pa. 19104

Balance of fee (to be announced) will be paid at the ALA Central Tickets desk, where tickets will be picked up.

Thursday, June 26

2:00-4:00 p.m. Organizational Meeting (cont.)

Formulation of objectives, long term plans and projects.

\section{Chairman's Letter to the Art Libraries Subsection}

With this issue of $C \triangleleft R L$ News we are beginning what I hope will be a continuing activity of our group, a roundtable of problems, news and ideas written for and by art librarians. The benefits to other readers of this journal will be, hopefully, of some value. The success of this initial effort is due to the enthusiasm and hard work of Mrs. Florence DaLuiso of the State University of New York at Buffalo.

Those who met at Kansas City were agreed that the Art Subsection must devote itself to current problems faced by all art libraries. To that end, an Index Committee was formed consisting of Miss Judith Hoffberg of the University of Pennsylvania, Miss Alice McGrath of the Rhode Island School of Design, Mrs. Florence DaLuiso of the State University of New York at Buffalo, Mr. David Ryan of the Minneapolis Institute of Art and myself. The Committee is engaged in a retrospective indexing of Art International from its inception in 1957 through 1968. As you know, the Art Index has begun to index Art Intermational with the 1969 issue. We hope to publish the index in the near future.

Elsewhere in this issue you will find the results of the first group of titles gathered by the Reprint Committee chaired for the last two years by Miss Carol Selby of Eastern Michigan University and Mr. William Dane of the Public Library of Newark.

We are planning enough work sessions at the conference in Atlantic City so that we can hear reports from the present committees and discuss the purpose and direction of new committees and our organization as a whole. To that purpose I would appreciate hearing any suggestions for discussion that you feel would be valuable.

The Nominating Committee under the chairmanship of Miss Alice McGrath has given us a slate of candidates with a much broader geographic base. Let us hope that more active participation from all parts of our country and Canada soon becomes a reality.-Herbert Scherer, Chairman, Art Subsection.

\section{Art Subsection Titles for Reprinting and Microfilming}

At the business meeting of the Art Subsection at the ALA Convention in New York in 1966, a suggestion was made to form a committee to investigate a program for microfilming and reprinting of unavailable source material in the field of art history. The membership felt that this was a worthwhile project as individual requests for reprinting had received scant attention from reprint publishers and microfilm companies.

A committee was appointed which included Carol Selby, then librarian at the Detroit Institute of Arts, as Chairman, with Herbert Scherer, art librarian of the University of Minnesota, and William J. Dane, principal art librarian, Newark Public Library, as committee members. The committee decided on the fol- 